\title{
Proteolysis of Sardine (Sardina pilchardus) and Anchovy (Stolephorus commersonii) by Commercial Enzymes in Saline Solutions
}

\author{
Chau Minh Le $e^{1,2}$, Claire Donnay-Moreno 2 , Sandrine Bruzac², Régis Baron², \\ Huong Thi My Nguyen ${ }^{3}$ and Jean Pascal Bergét* \\ ${ }^{1}$ College of Agriculture and Forestry, Thai Nguyen University, Quyet Thang, Thai Nguyen, Vietnam \\ ${ }^{2}$ IFREMER, rue de l'île d'Yeu, BP 21105, FR-44311 Nantes, France \\ ${ }^{3}$ Nha Trang University, 2 Nguyen Dinh Chieu, Nha Trang, Vietnam \\ ${ }^{4}$ IDMER, 2 rue Batelière, FR-56100 Lorient, France \\ Received: September 9, 2014 \\ Accepted: January 8, 2015
}

\begin{abstract}
Summary
Fish sauce production is a very long process and there is a great interest in shortening it. Among the different strategies to speed up this process, the addition of external proteases could be a solution. This study focuses on the effect of two commercial enzymes (Protamex and Protex 51FP) on the proteolysis of two fish species traditionally converted into fish sauce: sardine and anchovy, by comparison with classical autolysis. Hydrolysis reactions were conducted with fresh fish at a temperature of $30{ }^{\circ} \mathrm{C}$ and under different saline conditions (from 0 to $30 \% \mathrm{NaCl}$ ). Hydrolysis degree and liquefaction of the raw material were used to follow the process. As expected, the proteolysis decreased with increasing amount of salt. Regarding the fish species, higher rate of liquefaction and higher hydrolysis degree were obtained with anchovy. Between the two proteases, Protex 51FP gave better results with both fish types. This study demonstrates that the addition of commercial proteases could be helpful for the liquefaction of fish and cleavage of peptide bonds that occur during fish sauce production and thus speed up the production process.
\end{abstract}

Key words: hydrolysis, proteases, salt, sardine, anchovy, fish sauce

\section{Introduction}

As a traditional seasoning, fish sauce is still very popular in Southeast Asian countries despite the competition of soya sauce. The renewal of the consumer interest in authentic taste and traditional food has led to an increase in the fish sauce production (1). Even if some differences in processing can be observed among the producing countries, the basic principle is always quite similar. Fish is washed and mixed with salt (at a ratio ranging from 1:1 to $1: 5$ ) and the mixture is fermented at ambient temperature for a period varying from 5 to 24 months. The final product is a liquid rich in soluble proteins, peptides and amino acids with umami taste.
During fermentation, fish proteins are hydrolyzed under the action of proteases, the endogenic ones (mostly from the digestive tract) and those produced by halophilic bacteria (2). However, in the first days of this process, when the bacterial community is not yet established, it is considered that this initial proteolysis (liquefaction) is mostly due to the internal fish enzymes. Nevertheless, recent studies on sardine and anchovy have demonstrated that the activity of these internal enzymes decreases with increased $\mathrm{NaCl}$ concentration $(3,4)$.

As the major limitation of fish sauce production is the very long time of processing, different solutions to shorten it, especially the liquefaction of fish, have been stud- 
ied, such as the addition of concentrated exogenic proteolytic enzymes (5) or the use of selected bacteria as a starter culture (6). However, whatever the processing aid, it has to be halotolerant and active at ambient temperature in order to provide some process improvement.

\section{Materials and Methods}

In this study, two food-grade commercial proteases have been studied for their capacity to speed up the sardine and anchovy liquefaction occurring during the first step of fish sauce production at $30{ }^{\circ} \mathrm{C}$ and under saline conditions, reflecting the traditional processes used in Southeast Asia.

For this study, fresh sardines (Sardina pilchardus) from the Atlantic sea areas (Nantes, France) and frozen $\left(-20^{\circ} \mathrm{C}\right)$ anchovy (Stolephorus commersonii) from Nha Trang (Vietnam) were used. Before the experiment, raw material was left to adapt to room temperature and then crushed and homogenized using a blender.

The commercial large spectrum proteases used were Protamex and Protex 51FP, kindly provided by Novozymes A/S, Bagsværd, Denmark, and Genencor International B.V, Leiden, The Netherlands, respectively. Enzymatic hydrolysis was performed in a thermostatic batch reactor continuously stirred at $300 \mathrm{rpm}$. A mass of $500 \mathrm{~g}$ of fish (sardine or anchovy) was mixed with water ( $5: 1$ by mass) and $\mathrm{NaCl}$ if needed $(0,60,120$ or $180 \mathrm{~g})$. After adjusting to $30{ }^{\circ} \mathrm{C}$, the reaction was initiated by adding $1 \%$ of enzymes (by mass of raw material). The $\mathrm{pH}$ was monitored but not controlled. Samples of $40 \mathrm{~mL}$ were regularly taken, heated at $80^{\circ} \mathrm{C}$ for $20 \mathrm{~min}$ in order to inactivate the enzyme and then centrifuged at $20000 \times g$ for $30 \mathrm{~min}$. The resulting soluble and insoluble phases were then analyzed. Autolysis was estimated by conducting similar experiments without salt and without the addition of exogenous enzymes.

Dry matter, ash, protein and lipid contents were estimated as previously described (7). The content of organic matter in the soluble phase was then estimated as the result of the difference between dried and ash contents. The degree of hydrolysis (DH), which is defined as the ratio of the number of peptide bonds broken to the total number of peptide bonds per unit of mass, was also calculated and expressed in percentage (8). All the experiments were realized in triplicate and the analyses of variance were performed using Statgraphics Plus (Manugisitics Group, Inc, Rockville, MD, USA).

\section{Results and Discussion}

The average proximate chemical compositions (based on triplicates) of sardine and anchovy are given in Table 1 . They both contain a large quantity of water (66-78 \%), a relatively similar amount of proteins (16\%) and a low level of minerals (2-3\%). They mostly differ in their lipid content: $13 \%$ in sardine and $2 \%$ in anchovy.

As indicated, $\mathrm{pH}$ was not controlled but monitored. Initial $\mathrm{pH}$ was 6.9 of both fish, and decreased regularly during proteolysis. Final values recorded after six hours of experiments ranged from $6.5(0 \% \mathrm{NaCl}$ with Protex
Table 1. Proximate chemical composition (\% of raw material) of sardine (Sardina pilchardus) and anchovy (Stolephorus commersonii)

\begin{tabular}{lrr}
\hline & \multicolumn{2}{c}{$w / \%$} \\
\cline { 2 - 3 } & Sardine & Anchovy \\
\hline Moisture & $66.0 \pm 0.6$ & $78.3 \pm 0.7$ \\
Lipid & $13.5 \pm 0.2$ & $2.4 \pm 0.3$ \\
Protein & $16.0 \pm 0.3$ & $16.3 \pm 0.3$ \\
Ash & $2.7 \pm 0.4$ & $2.5 \pm 0.4$ \\
\hline
\end{tabular}

51FP) to 6.7 (control without exogenous protease), illustrating variable liberation of acidic compounds such as amino acids.

In order to compare the experiments despite the different salt contents, the soluble organic matter distribution was used instead of the dry matter one (Fig. 1). As expected, under the proteolytic actions of enzymes (internal and exogenous ones), the liquefaction of the matrix occurred after the cleavage of peptide bonds. Such shapes of hydrolysis curves were similar to those previously published: one initial fast reaction followed by a second slower reaction ending with a stationary phase $(8,9)$. However, great differences can be observed regarding the fish species, the type of enzyme and the mass fraction of $\mathrm{NaCl}$.

Prior to hydrolysis, only $(11 \pm 2) \%$ of the total organic content of the sardine can be recovered in the soluble phase (Fig. 1a), while in the anchovy this proportion was much higher $(26 \pm 1) \%$ (Fig. 1b). This can be explained by
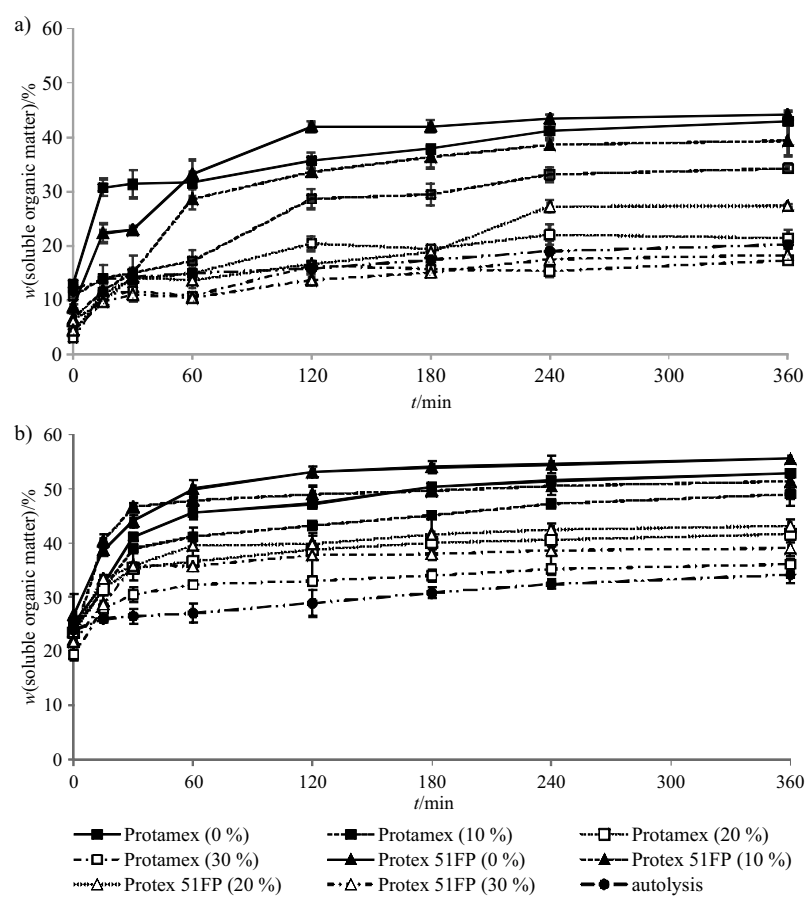

Fig. 1. Recovery of soluble organic matter $v$ s. time of hydrolysis obtained with Protamex and Protex 51FP under different saline conditions $(0,10,20$ and $30 \% \mathrm{NaCl})$ from: a) sardine and b) anchovy. The data represent the mean values \pm standard error of triplicate determinations 
the breakdown of the tissues of anchovy that occurred during freezing and thawing pretreatments. Such difference was still observed during all proteolysis experiments, with at least 10 to $20 \%$ of additional organic matter recovered in the anchovy supernatants.

As expected, even without the addition of any exogenous enzyme, the liquefaction of the organic matter was observed. This was due to the autolysis of the raw material, which is the consequence of the activities of endogenous enzymes, mostly the digestive ones as previously established (3-5). However, in most of the cases, after six hours the content of soluble organic material in the autolysates was lower than the one observed when enzymes were supplemented. At the end, in three experiments with sardine only, under high saline mass fractions (Protamex with $20 \% \mathrm{NaCl}$, Protamex with $30 \% \mathrm{NaCl}$, and Protex 51FP with $30 \% \mathrm{NaCl}$ ), no statistical differences were found when compared to autolysis.

Whatever the conditions (salt content or fish species), the liquefaction of the organic matter was always higher when using Protex 51FP than Protamex $(\mathrm{p}<0.05)$. This can be explained by a higher sensitivity of Protamex to $\mathrm{NaCl}$ or better affinity of Protex 51FP to substrates.

Except for the experiment on sardine with Protamex without salt, in all the other cases, the distribution of the organic matter in the supernatant reached a stationary phase within six hours of proteolysis. Moreover, the higher the $\mathrm{NaCl}$ content was, the sooner this plateau was reached and the lower the solubilization was. Based on these observations and comparison with autolysis, two hypotheses can be formulated: a competition between salt and organic matter in the soluble phase and/or a drastic reduction of enzymatic activity due to the presence of $\mathrm{NaCl}$.

Degree of hydrolysis $(\mathrm{DH})$, which indicated the percentage of cleaved peptide bonds (10), is one of the basic parameters that describe the properties of the hydrolysates, but also serves as indicator of protease activity and efficiency. Average hydrolytic curves of sardine and anchovy corresponding to autolysis, Protamex and Protex 51FP under different saline mass fractions are reported in Fig. 2. Whatever the fish species, enzyme or $\mathrm{NaCl}$ mass fraction, classical kinetics for enzymatic proteolysis was observed, characterized by an initial rapid phase where numerous peptide bonds were broken followed by a slowdown $(7-9,11,12)$. After six hours of reaction, regardless of the experiments, no stationary phase was observed. Moreover, the rate of DH increase did not slow down, indicating that both exogenous enzymes were still active even at $30 \%$ of $\mathrm{NaCl}$.

As expected, the greater the mass fraction of salt, the lower the $\mathrm{DH}$ values, reflecting a negative effect of $\mathrm{NaCl}$, probably the salting out, on the efficiency of the proteases $(2,13)$. However, some differences can be observed regarding the fish or the enzyme used. Under similar levels of salt, the resulting DH was always higher $(p<0.05)$ when using anchovy (Fig. 2b) compared to sardine (Fig. 2a). This may be explained by the freezing and thawing pretreatments but also by the difference in the activity of endogenous enzymes that contribute to the protein hydrolysis during fish sauce fermentation $(3,4)$.
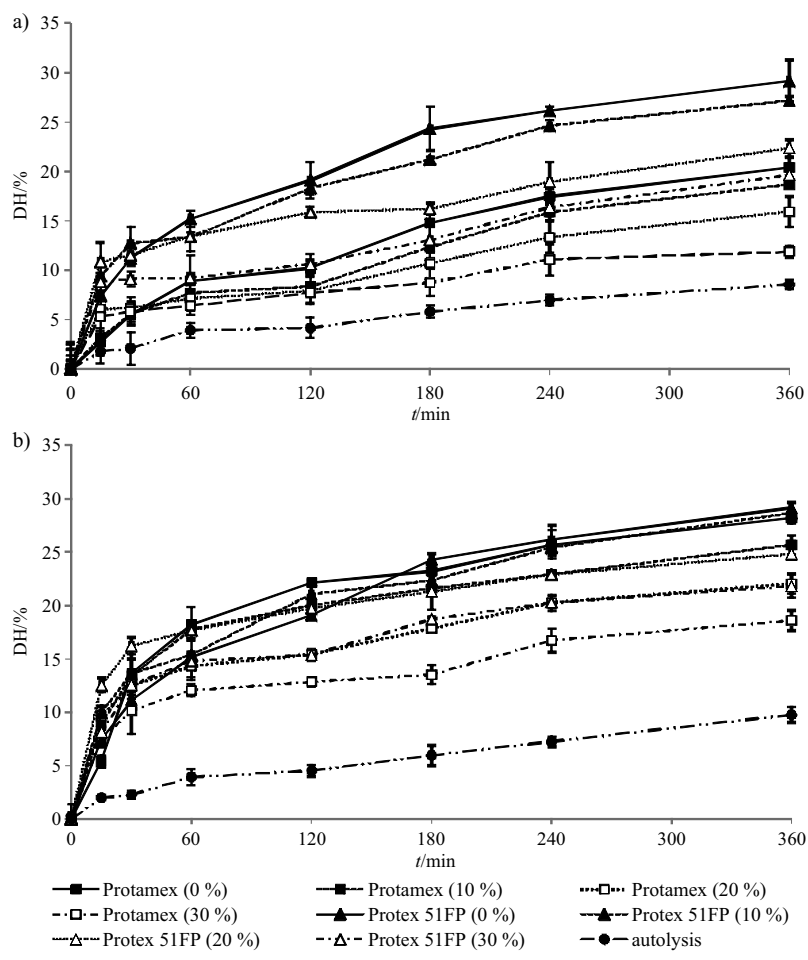

Fig. 2. Degree of hydrolysis vs. time of hydrolysis obtained without exogenous enzyme and with Protamex and Protex $51 \mathrm{FP}$ under different saline conditions $(0,10,20$ and $30 \% \mathrm{NaCl})$ from: a) sardine and b) anchovy. The data represent the mean values \pm standard error of triplicate determinations

Hydrolysis without any $\mathrm{NaCl}$ addition led to the maximum $\mathrm{DH}$ values $\left(\mathrm{DH}_{\max }\right)$. After six hours, in sardine they reached $(20.4 \pm 0.6) \%$ with Protamex (similar to the one previously published (14)) and (29.2 \pm 0.8$) \%$ with Protex 51FP, while in anchovy, $(28.2 \pm 0.1)$ and $(32.8 \pm 0.6) \%$ were obtained, respectively. With $10 \%$ of $\mathrm{NaCl}$, the $\mathrm{DH}$ values observed after six hours were reduced by about $7 \%$ (sardine with Protex 51FP) to $13 \%$ (anchovy with Protex 51FP), compared to $\mathrm{DH}_{\max }$. With $20 \%$ of salt in the media, these values decreased by $13 \%$ (with both enzymes in anchovy) to $23 \%$ (with both enzymes in sardine), and with $30 \%$ $\mathrm{NaCl}$, these reductions were about $33 \%$, except with Protamex in sardine (42\%). Nevertheless, even with these variations, it has to be noticed that whatever the conditions (fish species or $\mathrm{NaCl}$ content), the $\mathrm{DH}$ obtained after six hours of reaction was always higher with Protex 51FP compared to Protamex ( $\mathrm{p}<0.05)$.

Regarding autolysis, despite the lack of salt, the observed DH was always below the one obtained when Protamex or Protex 51FP were added. After six hours, the maximal DH obtained with sardine of $(8.5 \pm 0.5) \%$ and anchovy of $(9.8 \pm 0.7) \%$ was much lower than the one calculated when exogenous enzymes were added, even under high saline conditions (15).

\section{Conclusion}

This study confirms that the addition of commercial proteases may significantly contribute to the liquefaction of fish even under highly saline conditions by comparison to classical autolysis. Indeed, after six hours of experi- 
ments using exogenous enzymes, from 17 to $44 \%$ of the initial organic material were recovered in the soluble phase. However, the increase of the salt content negatively affected liquefaction, due to the competition between $\mathrm{NaCl}$ and proteins/peptides in the soluble phase and to the reduction of the enzymatic activity. Nevertheless, even in highly saline environment and at low temperature (30 ${ }^{\circ} \mathrm{C}$ ), the two enzymes tested in this study were still active after six hours, as illustrated by the continuous increase of the DH.

The addition of commercial proteases now has to be confirmed in the complete fish sauce production procedure (liquefaction and fermentation steps) by comparing the yield of liquefaction, sensory properties of the products and the overall process time length with those of the traditional process.

\section{References}

1. Park C, Raines RT. Quantitative analysis of the effect of salt concentration on enzymatic catalysis. J Am Chem Soc. 2001; 123:11472-9. http://dx.doi.org/10.1021/ja0164834

2. Klomklao S, Benjakul S, Visessanguan W, Kishimura H, Simpson BK. Purification and characterization trypsins from the spleen of skipjack tuna (Katsuwonus pelamis). Food Chem. 2007;100:1580-9. http://dx.doi.org/10.1016/j.foodchem.2006.01.001

3. Klomklao S, Kishimura H, Benjakul S. Endogenous proteinases in true sardine (Sardinops melanostictus). Food Chem. 2008;107:213-20.

http://dx.doi.org/10.1016/j.foodchem.2007.08.007

4. Siringan P, Raksakulthai N, Yongsawatdigul J. Autolytic activity and biochemical characteristics of endogenous proteinases in Indian anchovy (Stolephorus indicus). Food Chem. 2006;98:678-84.

http://dx.doi.org/10.1016/j.foodchem.2005.06.032

5. Beddows CG, Ardeshir AG. The production of soluble fish protein solution for use in fish sauce manufacture I. The use of added enzymes. J Food Technol. 1979;14:603-12. http://dx.doi.org/10.1111/j.1365-2621.1979.tb00907.x

6. Udomsil N, Rodtong S, Choi YJ, Hua Y, Yongsawatdigul J. Use of Tetragenococcus halophilus as a starter culture for flavor improvement in fish sauce fermentation. J Agric Food Chem. 2011;59:8401-8. http://dx.doi.org/10.1021/jf201953v

7. Soufi-Kechaou E, Dumay J, Donnay-Moreno C, Jaouen P, Gouygou JP, Bergé JP, et al. Enzymatic hydrolysis of cuttlefish (Sepia officinalis) and sardine (Sardina pilchardus) viscera using commercial proteases: Effects on lipid distribution and amino acid composition. J Biosci Bioeng. 2009;107: 158-64. http://dx.doi.org/10.1016/j.jbiosc.2008.10.018

8. Nguyen HTM, Sylla KSB, Randriamahatody Z, Donnay-Moreno C, Moreau J, Tran LT, et al. Enzymatic hydrolysis of yellowfin tuna (Thunnus albacares) by-products using Protamex protease. Food Technol Biotechnol. 2011;49:48-55.

9. Soufi-Kechaou E, Jaouen P, Ben-Amar R, Bergé JP. Influence of hydrolysis time on protein recovery and amino acid composition of hydrolysates from Sepia officinalis viscera. Science Research Reporter. 2012;2:115-29.

10. Adler-Nissen J. Determination of the degree of hydrolysis of food protein hydrolysates by trinitrobenzenesulfonic acid. J Agric Food Chem. 1976;27:1256-62. http://dx.doi.org/10.1021/jf60226a042

11. Randriamahatody Z, Sylla KSB, Nguyen TMH, Donnay-Moreno C, Razanamparany L, Bourgougnon N, et al. Proteolysis of shrimp by-products (Peaneus monodon) from Madagascar. Cyta-J Food. 2011;9:220-8. http://dx.doi.org/10.1080/19476337.2010.518250\#.VKu_wHv1PGs

12. Sylla KSB, Musabyemariya B, Bergé JP, Seydi M. Water ratio effect on the proteins hydrolysis tongue sole by-products (Cynoglossus senegalensis). RASPA. 2008;6:189-94.

13. Klomklao S, Benjakul S, Visessanguan W. Comparative studies on proteolytic activity of spleen extracts from three tuna species commonly used in Thailand. Food Biochem. 2004;28: 355-72. http://dx.doi.org/10.1111/j.1745-4514.2004.05203.x

14. Batista I, Ramos C, Mendonça R, Nunes ML. Enzymatic hydrolysis of sardine (Sardina pilchardus) by-products and lipid recovery. J Aquat Food Prod Technol. 2009;18:120-34. http://dx.doi.org/10.1080/10498850802581823\#.VKvBMXvlPGs

15. Ooshiro Z, Ok T, Une H, Hayashi S, Itakura T. Study on use of commercial proteolytic enzymes in production of fish sauce. In: Memoires of the Faculty of Fisheries, vol. 30. Japan: Kagoshima Univ.; 1981. pp. 383-94. 